Received $\quad 07.11 .2017$

Reviewed 18.12 .2017

Accepted 14.02.2018

A - study design

B - data collection

C - statistical analysis

D - data interpretation

E - manuscript preparation

F - literature search

\section{Water erosion on marl slopes and prevention of its effects using conservation of water and soil systems in the Wadi Isser watershed - Algeria}

\author{
Mohamed ZOBIRI ${ }^{1) A B D E F} \bowtie$, Mohamed MAZOUR ${ }^{2) A B D E}$, \\ Boutkhil MORSLI ${ }^{3)}$ ABDE
}

\footnotetext{
1) University of Tlemcen, Department of Forest Resources, Cité Sidi Zouaoui Ouled Mimoun, 13140 Tlemcen, Algeria; e-mail: zoubiriforestier@yahoo.fr

${ }^{2)}$ University Center of Aïn Témouchent, Algeria; e-mail: mohamed_mazour@yahoo.fr

${ }^{3)}$ National Institute of Forest Research, Algiers, Algeria; e-mail: morsli_boutkhil@yahoo.fr
}

For citation: Zobiri M., Mazour M., Morsli B. 2018. Water erosion on marl slopes and prevention of its effects using conservation of water and soil systems in the Wadi Isser watershed - Algeria. Journal of Water and Land Development. No. 37 p. 161-169. DOI: 10.2478/jwld-2018-0035.

\begin{abstract}
Water erosion remains a major concern on the marly slopes. Where erosive processes continue to increase and continue to pose serious problems and where knowledge is still insufficient on erodibility and its evolution and on solutions to soil erosion problems. The aim of this work is to contribute to the understanding of the functioning of soils on marl substrate in relation to erosion and to evaluate the effectiveness of the anti-erosion measures used in this type of environment. The Isser watershed, where several anti-erosion techniques were used, is the subject of this study. The analysis of the anti-erosion installations shows that most of the developments have been made according to standards and have worked well. But their effectiveness is different from one technique to another. The earthen thresholds seem to be the most suitable and the most effective. The effectiveness of earthen structures is summed up in stability, durability, cost-effectiveness, sediment storage, flood plating and water storage for a significant length of time, and had a positive impact on reducing erosion and the silting rate of the dam. The gabion thresholds also have a better stability and a good seating, but they are very sensitive and can undergo damage that reduces their effectiveness with regard to erosion. Dry stone thresholds are the least desirable and are often inadequate and inefficient in this type of terrain. A purely mechanical and/or biological vision in this type of environment is however insufficient, the mechanical arrangements associated with the biological developments are more effective.
\end{abstract}

Key words: efficiency of conservation of water and soil, erosion, marl, siltation, Wadi Isser watershed

\section{INTRODUCTION}

The Mediterranean area has a reputation for being subject to very high erosive risks [BOUCHELKIA et al. 2014; HUDSON 1991; REMINI et al. 2015; SELMI, KHANCHOUL 2016]. In Algeria, 45\% of the fertile land has been damaged by erosion and the average annual specific erosion varies between 2000 and 4000 $\mathrm{Mg} \cdot \mathrm{km}^{-2}$ [DEMMAK 1982], thus classifying Algeria among countries with the most erodible soil [TOUAIBIA 2010; TOUAIBIA et al. 2000]. Erosion is a serious environmental, agricultural and social problem, which affects and threatens huge areas in Algeria [MEGHRAOUI et al. 2017]. Water erosion remains a major concern mainly on the marly slopes where erosive processes continue to increase and continue to pose serious problems: land degradation, siltation of dams, destruction of infrastructure and flooding. The clayey 
soils formed on the marly slopes (vertic soils) occupy large areas in Algeria and represent great potentialities but also great risks such as erosion by their very particular hydrodynamic behaviour [GOMER 1992; KOURI et al. 1997; MORSLI, HABI 2014; RoOSE 1996].

On these marly slopes, where erosion begins and flood points are formed, there is still insufficient knowledge about erodibility and its evolution and the solutions to be advocated. Much work remains to be done to understand and apprehend erosive processes and to reduce risks. Although much research has been devoted to these problems, knowledge is still incomplete and there is still considerable uncertainty, particularly with regard to the erosion of marl areas and the effectiveness of anti-erosion techniques.

The consequences of water erosion on this type of marly land are disastrous and spectacular, threatening the dams by siltation. These infrastructures are threatened by clogging and premature silting, and about 20 million $\mathrm{m}^{3}$ are deposited each year in dam [REMINI 2000], resulting in a reduction in water availability. Erosion must prompt us to think several times about the choice of appropriate facilities [HABI, MORSLI 2010]. Algeria has made a considerable effort to protect watersheds and to fight the silting up of dams, but opinions are still divided between success and failure of these developments. In this order, many antierosion techniques have been applied to erosion control; however, each intervention area has its specificity, and prejudged efficient techniques are sometimes disappointing [DEYMIER 1995].

In view of this situation, there has been a need for research in this field, and more particularly on the efficiency of these developments. Anti-erosion control requires, first of all, a good knowledge of the behaviour of the material with respect to erosion. The objective of this work is to contribute to the understanding of the functioning of soils on marly substrate with regard to erosion and to evaluate the effectiveness of the anti-erosive installations used in this type of environment.

\section{METHODS}

The methodological approach chosen to carry out this work is essentially based on the study of the soils behaviour formed on marls (vertic soils) and on the study of the effectiveness of the erosion control measures practiced.

* Study of the hydrodynamic behaviour of clayey substrates formed on marly substrates: it is essential to understand the erosive functioning of watersheds on marly substrate for anti-erosion control. This study required the characterization of lithology, mineralogical composition, hydrodynamic and structural behaviour of soils and its susceptibility to erosion. The rain simulation is used for the study of hydrodynamic behaviour (use of the rain simulator of the ORSTOM type).
* Analysis of the effectiveness of the anti-erosion projects:

- Identification and classification of conservation of water and soil (CWS) developments. It is based on field surveys, bibliographic research, inquiries in the field and the counting of preestablished questionnaires.

- Spatialization of CWS developments (location and distribution of spatial planning). Georeferencing of anti-erosion installations using GPS and ARCGIS software 10.1.

- Analysis of the behaviour of the installations and evaluation of their effectiveness according to several criteria:

- Design and construction: the construction of the threshold must be started from the upstream downstream of the ravine. The materials used for the construction vary according to the types of threshold to be installed and must meet the standards of construction of the dams (implantation, calculation of the spacing between the thresholds, determination of numbers, foundation, anchoring of thresholds, weirs)

- Stability: a threshold is stable when it tends to maintain its initial position in stable equilibrium without deformation or movement for a long enough period (in this case more than 10 years). This stability is linked to a good foundation, sufficient lateral anchorage and a good choice of construction materials

- Adaptability: this is a concept introduced recently in torrential correction which consists in characterizing the capacity of torrential correction threshold to adapt to the conditions of the natural environment while playing its role.

- Cost and efficiency: efficiency, an effective correction threshold is the one that plays its role correctly and meets the objectives for which it was achieved namely (reduce gullying, storing sediments, compensate the slope).

- Maintenance and monitoring of developments: Permanent maintenance of the installations increases the service life of the structure and the effectiveness of the fight against siltation.

- Impact of development: the impact of a development can be defined as the difference between the situation with development and no development. This concept "with and without" is the foundation of the analysis of developments.

\section{STUDY AREA}

The Isser watershed, which is the subject of this study, covers an area of $1137 \mathrm{~km}^{2}$ and is located North-West of Algeria and is part of the Wadi Tafna watershed (Fig. 1). The climate is semi-arid of Medi- 


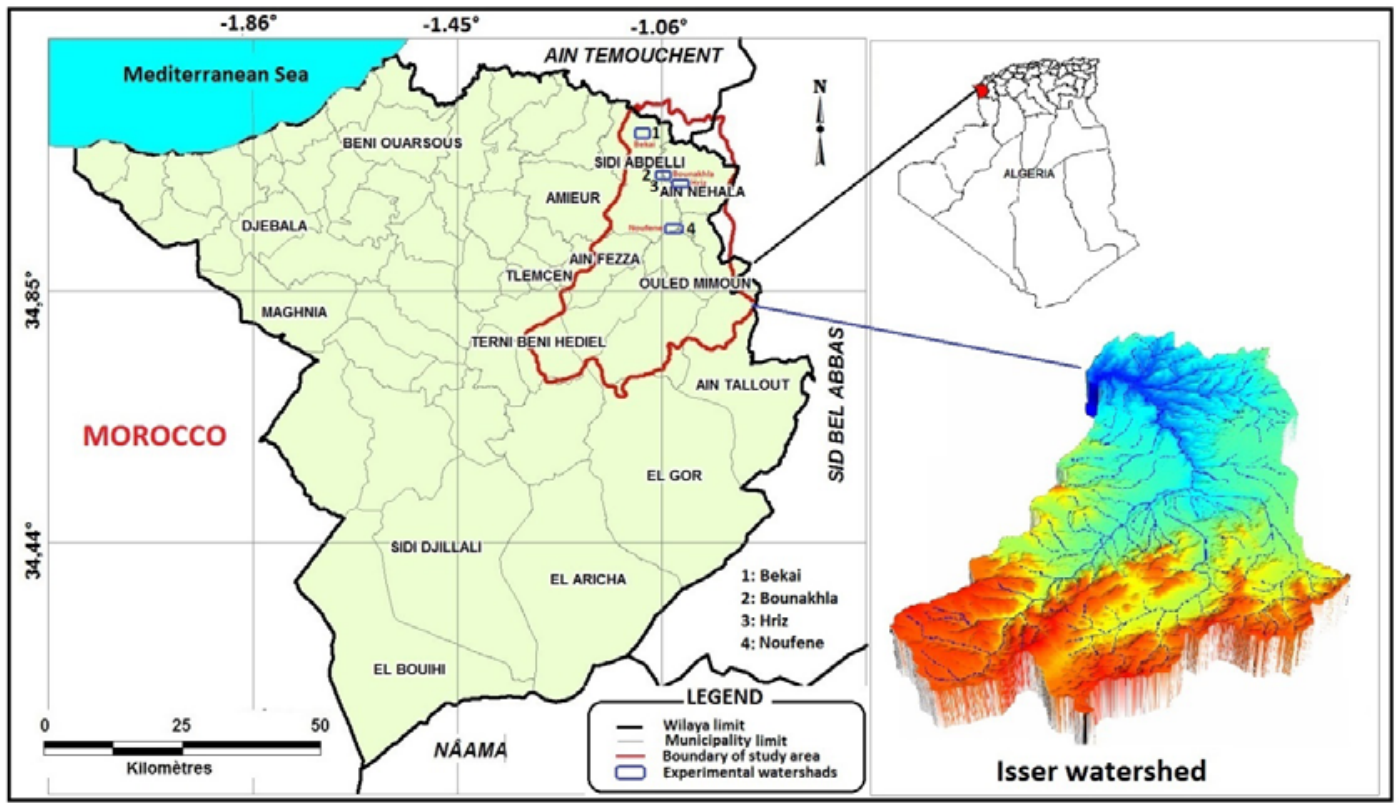

Fig. 1. Location of study area; source: own elaboration

Table 1. Characteristics of the experimental watersheds studied

\begin{tabular}{|c|c|c|c|c|c|c|c|}
\hline $\begin{array}{c}\text { Experimental } \\
\text { watersheds }\end{array}$ & $\begin{array}{c}\text { Surface } \\
\text { ha }\end{array}$ & $\begin{array}{c}\text { Marly surface } \\
\text { ha }\end{array}$ & $\begin{array}{c}\text { Extensive } \\
\text { cultures cereals } \\
\% \\
\end{array}$ & $\begin{array}{c}\text { Difference } \\
\text { in altitude } \\
\mathrm{m}\end{array}$ & $\begin{array}{l}\text { Gully length } \\
\text { km }\end{array}$ & $\begin{array}{c}\text { Mean slope } \\
\%\end{array}$ & $\begin{array}{c}\text { Specific } \\
\text { degradation } \\
\mathrm{Mg} \cdot \mathrm{km}^{-2} \cdot \mathrm{yr}^{-1}\end{array}$ \\
\hline Bekai & 165 & 165 & 60 & 250 & 2.1 & 25.73 & 5629 \\
\hline Bounakhka & 597 & 597 & 86 & 285 & 6.4 & 17.81 & 4267 \\
\hline Hriz & 151 & 151 & 100 & 180 & 2.4 & 14.39 & 2829 \\
\hline Noufene & 564 & 514 & 90 & 150 & 8.7 & 23.22 & 5312 \\
\hline
\end{tabular}

Source: own elaboration.

Table 2. Evaluation of erosion in experimental sub-watersheds (application of the Wischmeier equation)

\begin{tabular}{|l|c|c|c|c|c|c|c|c|c|r|r|r|}
\hline $\begin{array}{c}\text { Experimental } \\
\text { watersheds }\end{array}$ & $\begin{array}{c}I \\
\mathrm{~mm} \cdot \mathrm{h}^{-1}\end{array}$ & $\begin{array}{c}E \\
\mathrm{~J} \cdot \mathrm{m}^{-2}\end{array}$ & $\begin{array}{c}I_{30} \\
\mathrm{~mm} \cdot \mathrm{h}^{-1}\end{array}$ & $\begin{array}{c}R \\
\mathrm{Mg} \cdot \mathrm{yr}^{-1}\end{array}$ & $\begin{array}{c}S / L \\
\mathrm{~km}\end{array}$ & $\begin{array}{c}L S \\
\%\end{array}$ & $K$ & $C$ & $\begin{array}{c}P \\
\mathrm{Mg}^{2} \mathrm{ha}^{-1} \cdot \mathrm{yr}^{-1}\end{array}$ & $\begin{array}{c}\text { Erosion } T=A \cdot S \\
\mathrm{Mg} \cdot \mathrm{yr}^{-1}\end{array}$ \\
\hline Bekai & 70 & 28 & 84 & 2.1 & 0.41 & 23.78 & 0.66 & 0.90 & 0.90 & 26.69 & 4403 \\
\hline Bounakhka & 68 & 27 & 82 & 2.0 & 0.93 & 19.04 & 0.70 & 0.81 & 0.85 & 18.44 & 11010 \\
\hline Hriz & 68 & 27 & 82 & 2.0 & 0.53 & 10.14 & 0.66 & 0.89 & 0.80 & 9.67 & 1460 \\
\hline Noufene & 67 & 27 & 80 & 2.0 & 0.64 & 24.91 & 0.61 & 0.91 & .90 & 24.88 & 14032 \\
\hline
\end{tabular}

Explanations: $I=$ maximum intensity of rain $\left(\mathrm{mm} \cdot \mathrm{h}^{-1}\right) ; E=$ average rain energy $\left(\mathrm{J} \cdot \mathrm{m}^{-2}\right) ; I_{30}=$ mean intensity of rain for a duration of $30 \mathrm{~min}$ $\left(\mathrm{mm} \cdot \mathrm{h}^{-1}\right) ; R=$ rain aggressive factor $\left(\mathrm{Mg} \cdot \mathrm{yr}^{-1}\right) ; S / L=$ surface/gully length $(\mathrm{km}) ; L S=$ topographic factor that depends on slope and length (\%); $K=$ soil factor, characterizes soil erodibility; $C=$ plant protection factor; $P=$ factor of cultural practices and anti-erosion techniques; $A=$ loss of soil due to erosion $\left(\mathrm{Mg} \mathrm{ha}^{-1} \cdot \mathrm{yr}^{-1}\right) ; T=$ total erosion of the watershed per year $\left(\mathrm{Mg}^{-1} \mathrm{yr}^{-1}\right)$.

Source: own study.

terranean type with precipitation ranging from 370 to $425 \mathrm{~mm} \cdot \mathrm{yr}^{-1}$, characterized by short durations and high intensity. The maximum liquid flow recorded at the Isser station is $277 \mathrm{~m}^{3} \cdot \mathrm{s}^{-1}$, brought during the 14.03.1991 flood with a suspended solids concentration of $20 \mathrm{~g} \cdot \mathrm{dm}^{-3}$, while the largest suspension in sediment concentration was $102 \mathrm{~g} \cdot \mathrm{dm}^{-3}$ corresponding to a $25 \mathrm{~m}^{3} \cdot \mathrm{s}^{-1}$ liquid flow rate during October 2001 . The watershed has an elongated shape $(K c=1.6)$ with the length of the main gully of $81 \mathrm{~km}$ and that of the gullies of the lateral branches of $3640 \mathrm{~km}$. The surface waters of the Isser watershed are regulated by the Sidi El Abdelli El Izdihar dam with a capacity of $110 \mathrm{hm}^{3}$. The dominant lithological formation is Jurassic limes tones and dolomites (38\%) and marls $(30 \%)$. The data of the four experimental micro-watersheds, repre- sentative of the marl zone (Tab. 1, 2), clearly show the characteristics of the marly zone.

\section{RESULTS AND DISCUSSION}

\section{STUDY OF THE HYDRODYNAMIC BEHAVIOUR OF CLAY-LIKE STRUCTURES FORMED ON MARLY SUBSTRATES}

The characterization of the soils formed on marls shows that the soils are essentially vertic soils: limestone brown, little evolved, regosols and vertisols. Their essential character is their homogeneity linked to the constant mixing of the horizons by the vertic movements. They are rich in limestone and saturated with calcium and magnesium. The swelling clays, by 
alternating swelling and shrinkage, cause vertic movements and the frequent appearance of shrinkage slots.

The marls present a significant weathering horizon. This horizon is the result of the interaction of meteoric alteration agents (freezing, thawing, moistening, and desiccation). This mantle of bumps is characterized by a progressive structuring which is accompanied by an increase of the porosity. This will facilitate the infiltration of rainwater by a hypodermic flow.

On all these soils, erosion is quite strong, in rivulets/trenches, in gullies, in suffosion and in the form of landslides. The cracks in the soil into which the hypodermic runoff plunges will gradually transform into tunnels, which collapse and form regressive gullies that progress rapidly during the heavy showers. The scouring of water at the level of the gullies causes the appearance of a traction sliding from bottom to top. Gullies are of $\mathrm{V}$ type and may be active or stable. Erosion in some areas is extremely high, even down to denudation of the bedrock and to badlands.

The monitoring of these soils on a yearly scale shows that dry soils are characterized by a dense network of cracks; the first rains are unlikely to cause runoff. The network of cracks makes it possible to transport water quickly in depth, which sometimes allows an internal export of materials, as long as the cracks are open. The phenomena of suffosion (internal erosion) can thus be explained. The results show that imbibition rainfall (runoff trigger threshold) often varies from a rain of imbibition $\left(P_{i}\right)$ of $30 \mathrm{~mm}$ on dry and cracked soil to less than $2 \mathrm{~mm}$ in wet and closed soil. $P_{i}$ can decrease by thirty times, once the soil is closed due to the swelling clays phenomenon.

The results show a highly significant relationship between $P_{i}$ and open surfaces $\left(R^{2}=0.89\right)$. These open surfaces largely determine the soils behaviour with regard to runoff and erosion. Monitoring of soil structural functioning (changes in soil surface characteristics) and hydrodynamic behaviour, due to the clays shrinkage and swelling phenomenon, also allowed us to explain the variations of soil behaviour with respect to erosion at the year scale. The first cracks are detectable below a humidity of about $27 \%$ and the shrinkage reaches its maximum of $5 \mathrm{~cm}$-width around a moisture content of $14 \%$. The extent of the shrinkage-swelling phenomenon is related to the mineralogical composition of the clay phase [OLCHAWA, GORĄCZKO 2012].

The clay soils studied, formed on marls, are characterized by a richness of clay that exceeds $50 \%$. The mineralogical composition of the clays is of type $2: 1$ [CHEBANI 1996]. This type of swelling clay is sensitive to dispersion and cracking (high susceptibility to the shrinkage-swelling phenomenon). Swelling clays are very sensitive to variations in humidity [ROBITAILLE, TREMBLAY 1997].

The extent of cracking is related to the clay content and especially to the crystallographic nature of some clays [COLLINET, ZANTE 2002]. The results of the realized geotechnical tests show that the marly formation is very plastic and swelling $(33<I p<42$ and $0.05<C g<0.08-$ where $I p=$ plasticity index, $C g=$ swelling coefficient); once the marl has been humidified, its cohesion falls and produces its softening, which accelerates the collapse and sliding under the effect of the rather heavy structures such as heavy anti-erosive installations.

Infiltration is strongly related to this structural soil dynamics, it goes from more than $500 \mathrm{~mm} \cdot \mathrm{h}^{-1}$ in the dry and cracked state to less than $15 \mathrm{~mm} \cdot \mathrm{h}^{-1}$ in the wet state. During summer thunderstorms, all the water flows and head for cracks (preferential flow) and can cause internal erosion and soil movements, especially at the natural outfalls where torrential correction installations are.

In wet conditions and after soil closure and soil compaction by rainfall, runoff is easily triggered even with light rainfall. The results of the simulated rainfall showed that run-off water is relatively less precocious at first, but once runoff begins to cut the soil, creating claws, it becomes more erosive and transport tends to increase (from 10 to more than $100 \mathrm{~g} \cdot \mathrm{dm}^{-3}$ ) following the shearing of the claws and trenches lips. Clay soils are sensitive to shear forces [PHAM 2008]. The estimated erodibility factor value by the WISCHMEIER et al. [1971] is 0.10 and the instability index is 0.6 (Henin index), thus classifying this type of soil as resistant to the erosion patch.

MORSLI [2005] shows that the erodibility factor for this type of soil (obtained by the Wischmeier and Smith equation [WISCHMEIER, SMITH 1978] from the results on experimental plots) varies between 0.002 and 0.008 , showing good resistance to rain energy.

In fact, if these vertic soils are resistant to rainfall energy, they remain very sensitive to runoff energy because of their very special hydrodynamic behaviour (shrinkage-swelling phenomenon of the clays) and their low shear strength. When cracked, infiltration is very high and internal erosion can occur. These infiltrations may promote suffosion phenomena and mass movements. Once rehydrated, the runoff is so strong that it causes gullying. Despite their good structural stability, the vertic soils remain very sensitive to erosion due to their particular hydrodynamic behaviour. Once these latter cracked, infiltration is very high and internal erosion can be induced. In the more saturated state, the imbibition rain becomes very weak (from 1 to $2 \mathrm{~mm}$ ), which easily triggers the runoff. Abundant runoff characterized by high energy digs the soil and causes shear. If these soils are resistant to groundwater erosion, they remain sensitive to gullying. Gully erosion can reach $100-300 \mathrm{Mg} \cdot \mathrm{ha}^{-1} \cdot \mathrm{yr}^{-1}$ in marly areas [MoRSLI, MALla 1995; RoOSE et al. 2000]. On the slope, the runoff energy prevails over that of the rains. The resistance of a soil profile to runoff is different from the erodibility of a soil to the raindrops. For erosion control in this type of environment and the reduction of sediment transfer to dams, it is necessary to focus on linear erosion at the level of the ravines that provide most of the sediments. 


\section{ANALYSIS OF THE EFFECTIVENESS OF CONSERVATION OF WATER AND SOIL (CWS) FACILITIES}

1. Identification and spatialization. This study, based on surveys and investigations, made it possible to identify several types of anti-erosion installations: torrential correction with earth, gabion and dry stone. The spatialization of these developments, carried out with GPS and ARCGIS software, allowed us to have the map of their distribution in space (Fig. 2). This map shows a variability of CWS developments in the marly area.

2. Analysis of the behaviour of the installations and evaluation of their effectiveness. The realization volume of each type of threshold gives us a first interpretation on the importance of the interventions (Tab. 3).

An erosion control and watershed protection assessment involves a confrontation between, on the one hand, the erosive processes, the evaluation of their degree of destruction, the nature and size of the protective arrangements; and, on the other hand, the nature and importance of the issues that are threatened by these erosive processes [MEUNIER 1992]. In this marly area, we have already characterized the hydrodynamic behaviour and quantified the erosive processes and the degree of sensitivity.

The analysis of the prospective two-decade development projects aimed at protecting the watershed and the silting up of the Izdihar dam showed that $30 \%$ of the gabion (SG) and stone thresholds (SP) did not work due to their implantation in non-active gullies. Effective anti-erosion control requires a good knowledge of the erosive dynamics involved [MORSLI et al. 2004]. On the other hand, the earthen thresholds (ST) have all worked well; the choice of sites of implantation was well studied.

\section{Thresholds design and development}

One of the reasons of success or failure is also to be found in the general design criteria. The problem posed by the torrential correction is that of the choice of the type of thresholds to be installed, the location, the dimensioning, the efficiency and the cost. The results show that the majority of the developments were made according to standards.

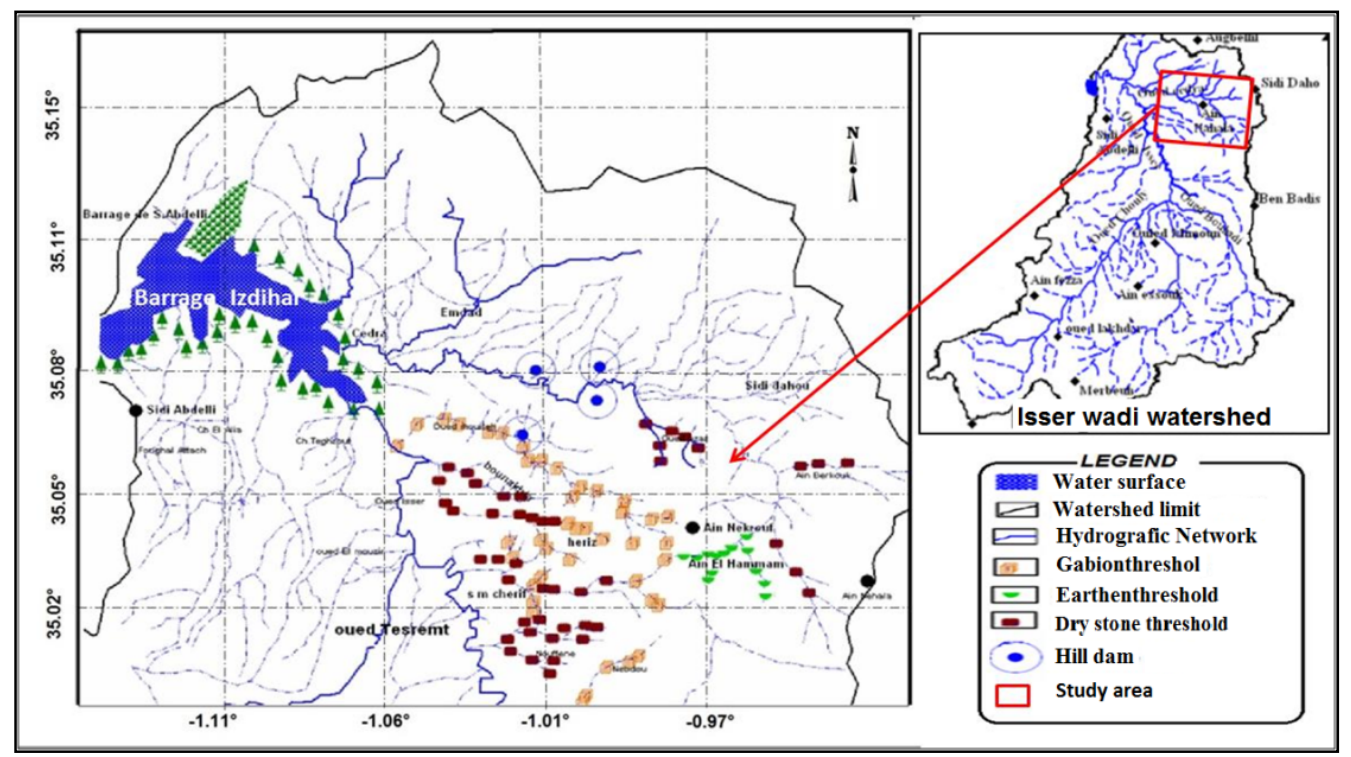

Fig. 2. Types of development upstream of El Izdihar dam; source: own elaboration

Table 3. Anti-erosion installations upstream of the El Izdihar dam

\begin{tabular}{|c|c|c|c|c|c|c|c|c|c|c|c|c|c|}
\hline \multirow{2}{*}{$\begin{array}{c}\text { Threshold } \\
\text { types }\end{array}$} & $N$ & $\begin{array}{c}L \text { av. } \\
(S D) \\
\mathrm{m}\end{array}$ & $\begin{array}{c}l \text { av. } \\
(S D) \\
\mathrm{M}\end{array}$ & $\begin{array}{c}H \text { av. } \\
(S D) \\
\mathrm{m}\end{array}$ & $\begin{array}{c}V \text { av. } \\
\mathrm{m}^{3}\end{array}$ & $\mathrm{Anc}$ & $\mathrm{Wr}$ & $\begin{array}{c}S p \text { av. } \\
\mathrm{M}\end{array}$ & $\mathrm{F}$ & $\begin{array}{c}\text { con- } \\
\text { struction } \\
\text { year }\end{array}$ & $\begin{array}{c}\text { Ef. } \\
\%\end{array}$ & $\begin{array}{c}\text { St. } \\
\%\end{array}$ & $\begin{array}{c}\text { Ad. } \\
\%\end{array}$ \\
\hline $\begin{array}{c}\text { Earthen } \\
\text { threshold }\end{array}$ & 48 & $\begin{array}{c}42.35 \\
(6.67)\end{array}$ & $\begin{array}{c}2.83 \\
(0.34)\end{array}$ & $\begin{array}{c}6.10 \\
(0.72)\end{array}$ & 744 & $\mathrm{good}$ & $\mathrm{GD}$ & 77 & $\mathrm{good}$ & 1986 & 70 & 71 & 84 \\
\hline $\begin{array}{c}\text { Gabion } \\
\text { threshold }\end{array}$ & 759 & $\begin{array}{c}12.04 \\
(3.36)\end{array}$ & $\begin{array}{c}1.21 \\
(0.43)\end{array}$ & $\begin{array}{c}1.43 \\
(0.36)\end{array}$ & 22 & $\mathrm{good}$ & $\mathrm{GD}$ & 16 & $\mathrm{good}$ & 1986 & 44 & 49 & 35 \\
\hline $\begin{array}{c}\text { Dry stone } \\
\text { threshold }\end{array}$ & 505 & $\begin{array}{c}5.26 \\
(1.81)\end{array}$ & $\begin{array}{c}1.70 \\
(0.23)\end{array}$ & $\begin{array}{c}1.07 \\
(0.23)\end{array}$ & 9.96 & $\mathrm{bad}$ & $\mathrm{Pd}$ & 10 & $\mathrm{bad}$ & 1999 & 29 & 30 & 22 \\
\hline
\end{tabular}

Explanations: $N=$ number; $L=$ length; $l=$ width; $H=$ height; $V$ av. = average volume; Anc = anchoring of installations; $\mathrm{Wr}=$ weirs; $S p$ av. $=$ spacing between the thresholds; F = foundation; $(S D)=$ standard deviation; Ef. = effectiveness; St. = stability; Ad. = adaptability; $\mathrm{Gd}=$ good design; $\mathrm{Pd}=$ poor design. All the developments realized in these watersheds have been studied.

Source: own study. 


\section{Stability and adaptability}

The earthen thresholds (ST) are characterized by a good stability and a better efficiency with regard to sediment halt. Their stability is linked to the respect of construction standards and to the used type of materials. They have functioned as sediment traps. Accumulations of sediments upstream of the structures have favoured the installation of a spontaneous plant cover, which made it possible to fix the sediments and to stabilize the structure even more. To reduce the risk of downstream movement, sediments must be fixed quickly by vegetation [RoOsE et al. 2000]. The results show that they are very compatible with this type of environment and remain the best adapted in this type of marly terrain. There is a very good harmony between this type of development and the environment. The gabion thresholds (SG) also have a better stability and a good seating. On the slopes, they remain sensitive and can suffer damage that reduces their effectiveness with regard to erosion (torsion, curvature, scour, fox effect, too heavy structures causing slippage). A good relationship was found between the stability and slope of the gabion location $\left(R^{2}=75 \%\right)$, many deformations and scours were found on slopes greater than $20 \%$. The gabion thresholds can be destroyed by the Renard formation [RoOSE et al. 2000]. Also the effectiveness of this type of threshold is related to the anchoring $\left(R^{2}=85 \%\right)$ and the foundation $\left(R^{2}=75 \%\right)$.

The dry stone thresholds (SP) are the least stable, especially when they are planted on a slope; a large part is damaged for many reasons (not adapted to marly land, choice of stones, etc.). The relation obtained between the stability and the slope of the location of the thresholds $\left(R^{2}=85 \%\right)$ clearly shows the effect of the slope in this type of marly environment. Some dry stone thresholds have some apparent stability due either to their installation in inactive gullies or to the absence of large flows. Conservation of water and soil (CWS) are often inadequate and inefficient in this type of terrain. Some anti-erosion control interventions have often had limited effectiveness [AVENARD 1990].

\section{Cost and effectiveness}

The protection of the watershed requires considerable investment. However, it is important to qualify the actual costs associated with developments considering all the economic ins and outs. It is also necessary to estimate the benefits associated with the protection of the dam and the slopes (reduction of erosion and siltation, selected sedimentary deposits, increase in water volumes, reduction in maintenance, etc.). The value of treatment cannot be judged solely on the basis of development costs, but the assessment of benefits must be taken into account. The numerical assessment of indirect effects is conditioned by the availability of information/data on the results showing changes in the results that occur with the development. It is sometimes difficult to establish all these parameters to evaluate the economic merits of antierosion and dams control measures.

The effectiveness of earthen structures is summarized in the stability, sediment storage, flood spreading and water storage for a non-negligible duration. ST are highly efficient and less costly than dry stone and gabion thresholds. The construction of the ST is advantageous and economical because the building materials are located in situ, which minimizes the total cost of production. A threshold in gabion, for the same volume, costs four times more than that in earth. In addition, ST retain more sediment and allow flood spreading while alleviating their violence and damage, which is more advantageous and therefore their cost is acceptable.

The cost-effectiveness is very economical. These developments remain the most efficient and least expensive that the other thresholds as well as the benches which were often practiced in Algeria and which have rarely proved their effectiveness. The large structures, deployed for the defense and restoration of soil (DRS) in Algeria for 40 years, very costly, have proved their low durability and often their low efficiency to fight erosion and siltation of dams [HAMOUDI et al. 2006].

\section{Maintenance and monitoring of developments}

Anti-erosive treatment is likely to succeed only if it has a minimum of maintenance, it must be constantly monitored to avoid degradation and allow rapid repair. The absence of maintenance for certain thresholds has made them very fragile and presents a risk of displacement of the retained sediments towards the dam. The lack of permanent facilities maintenance reduces the lifetime of the structure and the effectiveness of the fight against siltation [HADJIAT 1997]. The results show that most of these developments have not received any maintenance since their completion. Through the lack of maintenance, some damaged thresholds no longer fulfil their role and sometimes threaten those downstream.

\section{Impact of development}

The impact of a development can be defined as the difference between the situation with development and without development. This concept "with and without" is the foundation of the analysis of the developments. It is important not to lose sight of the fact that the situation as it stands today would probably not remain the same in the absence of adjustments. The imbalance of the aquatic environment (dams) has an inestimable cost. The anti-erosion works carried out in the Isser watershed have contributed to the reduction of erosion, but have also constituted a source of support for the residents who have used the water retained in the earth thresholds for their needs during 
certain years. The Italian study carried out by the Centro Studi e Richerche [1972] predicted more than $800,000 \mathrm{~m}^{3}$ of mud annually for the El Izdihar dam. If the dam is silted up, its de-silting will cost twice building of a new dam [REMINI 2000; REMINI et al. 2015]. It is important to recall that the Sidi El Abdelli Izdihar dam, with an initial volume of $110 \mathrm{hm}^{3}$ when it was impounded in 1988 , was $103 \mathrm{hm}^{3}$ according to the bathymetric survey of 2003 and $95 \mathrm{hm}^{3}$ in 2016 .

The realized developments made it possible to reduce the anticipated siltation rate by $45 \%$ and thus to gain a volume of water of $18.5 \mathrm{hm}^{3}$ in the dam after 28 years. Sedimentation is the cause of considerable dams life-time shortening. According to the study by the Centro Studi e Ricerche [1974], the siltation rate would be $30 \%$ in 2016 , whereas it was of only $13.5 \%$ after the development of anti-erosive developments in the marly area. Assessing all the economic impacts of this CWS works is very difficult, as there are unavoidable results (environmental impact, protection of aquatic fauna, etc.).

It should be noted that the developments did not affect the entire catchment area but only part of the marly zone, the most productive zone of sediments. If the development had affected all areas of sediment production and with appropriate techniques and associated with biological techniques, the results would have been much better. In other places, the use of biological techniques has yielded partial results. A purely mechanical or biological vision in this type of environment is however insufficient, the mechanical arrangements associated with the biological developments are more effective.

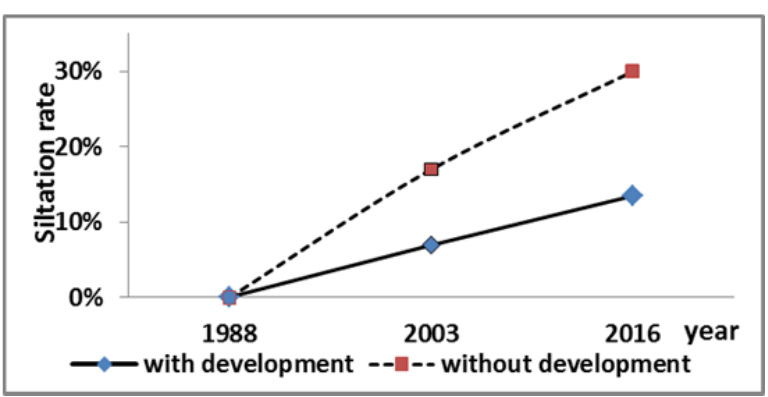

Fig. 3. Evolution of siltation rate in El Izdihar dam; source: own study

\section{CONCLUSIONS}

Water erosion remains a major concern on the marly slopes where the erosive processes are very complex and are constantly growing and causing serious problems. The follow-up of the structural functioning of the soil and the hydrodynamic behaviour, following the phenomenon of shrinkage-swelling of the clays, also allowed explaining the variations of this type of environment with regard to the erosion on the scale of the year. Vertical soils are resistant to rainfall energy, but they remain very sensitive to runoff energy and gullying $\left(100 \mathrm{Mg} \cdot \mathrm{ha}^{-1} \cdot \mathrm{yr}^{-1}<\right.$ gullying
$<300 \mathrm{Mg} \cdot \mathrm{ha}^{-1} \cdot \mathrm{yr}^{-1}$ ) due to their very particular hydrodynamic behaviour and to their low shear strength.

The analysis of the anti-erosion installations carried out over the past two decades, with the objective of protecting the watershed area and the fight against the El Izdihar dam silting up, shows that most of the developments have been made according to standards and have worked well. But their effectiveness is different from one technique to another. Earthen thresholds (ST) appear to be the most appropriate and effective. The effectiveness of earthen structures is summed up in stability, durability, economic cost-effectiveness, sediment storage, flood staggering and water storage for a significant length of time. The gabion thresholds (SG) also have a better stability and a good seating, but on slopes they remain very sensitive and can suffer damage that reduces their effectiveness with regard to erosion (torsion, curvature, scour, fox, and landslides). Dry stone thresholds (SP) are the least stable and are often ineffective in this type of terrain.

ST development has had a positive impact on reducing erosion and the dam siltation rate. It must be emphasized that any anti-erosion management is likely to succeed and lasts only if it has a minimum of maintenance, it must be constantly monitored to avoid degradation and allow for rapid repair. According to these results, it is clear that the ST, which have proved their effectiveness in this very difficult environment and which the local residents require, can be further improved (sizing, monitoring and maintenance, water storage, site selection...) to be even more adapted with natural and socio-economic conditions and can be introduced into a participatory approach to water and soil conservation. A purely mechanical or biological vision in this type of environment is however insufficient, the mechanical arrangements associated with the biological developments prove to be more effective.

\section{REFERENCES}

AVEnARD J.-M. 1990. Dynamique érosive actuelle en Afrique du Nord [Current errossive dynamics in north Africa]. Revue de la Faculté des Lettres Tétouan. Vol. 14 p. 37-43.

Bouchelkia H., Belarbi F., Remini B. 2014. Quantification of suspended sediment load by double correlation in the watershed of Chellif (Algeria). Journal of Water and Land Development. No. 21 p. 39-46. DOI 10.2478/ jwld-2014-0012.

Centro Studi e Ricerche 1974. Etude des bassins versants des Oueds Isser et Sikkak [Study of the of wadi Isser and Sikkak watersheds]. Alger. Secrétariat d'État aux forêts (SEFOR). 3rd vol. pp. 640.

CHEBANI R. 1996. Etude à différentes échelles des risques d'érosion dans le bassin versant de l'Isser [Study at different scales of risks of erosion in the Isser wadi watershed]. MSc Thesis. Alger. Institut National Agronomique pp. 135.

COLlinet J., ZANTE P. 2002. Le ravinement sur marnes gypseuses en Tunisie semi-aride [Gulse marl gully eruption in semi-arid Tunisia]. Bulletin du Réseau Érosion. Vol. 21 p. 301-319. 
DemmaK A. 1982. Contribution à l'étude de l'érosion et des transports solides en Algérie [Contribution to the study of erosion and solid transport in Algeria]. Mémoires des sciences de la terre. Vol. 82. Iss. 28 pp. 323.

DeYMieR C. 1995. Conception et calcul de barrages de correction torrentielle [Design and calculation of torrential correction dams].Grenoble. CEMAGREF pp. 286.

GoMeR D. 1992. Ecoulement et érosion dans des bassins versants à sols marneux sous climat semi-aride méditerranéen [Flow and erosion in water watershed with marly soils under semi-arid Mediterranean climate]. GTZ-ANRH pp. 207.

HABI M., Morsli B. 2010. Contraintes et perspectives des retenues collinaires dans le Nord-ouest algérien [Constraints and perspectives of hill dams in northwestern Algeria]. Sécheresse. Vol. 22. Iss. 1 p. 49-56.

HADJIAT K. 1997. Etat de la dégradation des sols en Algérie [State of land degradation in Algeria]. Rapport d'expertise, PNAE, Banque Mondiale, Washington DC pp. 45.

Hamoudi A., Morsli B., Roose E. 2006. Evaluation des méthodes classiques de défense et restauration des sols en Algérie [Evaluation of classical methods of defense and soil restoration in Algeria]. In: L'International Soil Conservation Organisation. Comptes rendus $14^{\mathrm{e}}$ conférence de l'ISCO. 14-19.05.2006 Marrakech).

HudSON N.W. 1991. A study of the reasons for success or failure of soil conservation projects. FAO Soil Bulletin. Vol. 64 pp. 65.

Kouri L., VoGT H., Gomer D. 1997. Analyse des processus d'érosion hydrique linéaire en terrain marneux, bassin de l'oued Mina, Tell Oranais, Algérie [Analysis of the processes of linear hydric erosion in marl land, Mina wadi watershed, Oranais Hill, Algeria]. ORSTOM Bulletin Réseau Érosion. Vol. 17 p. 64-73.

Meghraoui M., Habi M., Morsli B., Regagba M., SelaDJI A. 2017. Mapping of soil erodibility and assessment of soil losses using the RUSLE model in the Sebaa Chioukh Mountains (northwest of Algeria). Journal of Water and Land Development. No. 34 p. 205-213. DOI 10.1515/jwld-2017-0055.

MEUNIER M. 1992. L'érosion torrentielle dans la protection contre les risques naturels [Torrential erosion in the protection against natural risks]. Institut de Recherche pour le Developpement Marseille Cedex 02 p. 22-27.

MoRsLi B. 2015. Ruissellement et erosion: Analyse des facteurs conditionnels [Runoff and erosion: Conditional factor analysis]. PhD Thesis. Université de Tlemcen, Algérie pp. 180.

Morsli B., HaBi M. 2014. Effet du comportement hydrodynamique des sols argileux sur les risques de ruissellement et d'érosion du sol: cas des sols des montagnes méditerranéennes de Beni-Chougrane-Algérie [Effect of the hydrodynamic behavior of clay soils on the risks of runoff and soil erosion: the case of the soils of the Mediterranean mountains of Beni-Chougrane-Algeria]. Revue Zeitschrift für Geomorphologie (ZFG Germany). Vol. 58. No. 4 pp. 22.

Morsli B., Malla R. 1995. Méthodologie et description de la dynamique du ravinement dans les monts de Beni chougrane [Methodology and description of gully dynamics in the Beni Chougrane Mountains]. Rapport. Alger. INRF pp. 10.

Morsli B., Mazour M., Mededjel N., Hamoudi A., RoOSE É. 2004. Influence de l'utilisation des terres sur les risques de ruissellement et d'érosion sur les versants semi-arides du Nord-ouest de l'Algérie [Influence of land use on runoff and erosion risks on the semi-arid slopes of North-West Algeria]. Sécheresse. Vol. 15. Iss. 2 p. 96-104.

Olchawa A., GoraczKo A. 2012. The relationship between the liquid limit of clayey soils, external specific surface area and the composition of exchangeable cations. Journal of Water and Land Development. No. 17 p. $83-88$.

PHAM T.L. 2008. Erosion et dispersion des sols argileux par un fluide [Erosion and dispersion of clay soils by a fluid]. PhD Thesis. École Nationale des Ponts et Chaussées pp. 195.

REMINI B. 2000. L'envasement des barrages en Algérie: quelques exemples algériens [The siltation of dams in Algeria: some Algerian examples]. Bulletin du Réseau Erosion. Vol. 2. No. 20 p. 165-171.

REMini B., BENSAFia D., NASROUN T. 2015. Impact of sediment transport of the Chellif River on silting of the Boughezoul reservoir (Algeria). Journal of Water and Land Development. No. 24 p. 35-40. DOI 10.1515 /jwld-2015-0005.

Robitaille V., Tremblay D. 1997. Mécanique des sols (théorie et pratique) [Soil mechanics (theory and practice)]. Quebec, Canada. Modulo. ISBN 2891136586 pp. 652.

Roose E. 1996. Méthodes de mesure des états de surface du sol, de la rugosité et des autres caractéristiques qui peuvent aider au diagnostic de terrain, des risques de ruissellement et d'érosion, en particulier sur les versants cultivés des montagnes [Methods for measuring soil surface conditions, roughness and other characteristics that may assist in land diagnosis, runoff and erosion risks, particularly on mountain cultivated]. Bulletin du Réseau Erosion. Vol. 16 p. 87-97.

Roose E., Chebbani R., Bourougaa L. 2000. Ravinement en Algérie. Typologie, facteurs de contrôle, quantification et réhabilitation [Gully in Algeria. Typology, control factors, quantification and rehabilitation]. Sécheresse. Vol. 11(4) p. 317-326.

Selmi K., Khanchoul K. 2016. Sediment load estimation in the Mellegue catchment, Algeria. Journal of Water and Land Development. No. 31 p. 129-137. DOI 10.1515/jwld-2016-0044.

Mazour M. 2006. Analyse de quelques aménagements antiérosifs juste à l'amont du barrage de Hammam Boughrara (Moyenne-Tafna) Tlemcen (Algérie) [Analysis of some anti-erosion facilities just upstream of Hammam Boughrara dam (Moyenne-Tafna) Tlemcen (Algeria)]. Institut de Recherche pour le Developpement Marseille Cedex 02 p. 249-255.

Touaibia B. 2010. Problématique de l'érosion et du transport solide en Algérie septentrionale [The problem of erosion and solid transport in northern Algeria]. Sécheresse. Vol. 21 (1) p. 1-6.

Touaibia B., Gomer D., AidaOui A. 2000. Estimation de l'index d'érosion de Wischmeier dans les micro bassins expérimentaux de l'Oued Mina en Algérie du Nord [Estimation of the Wischmeier erosion index in the experimental micro-watershed of Mina wadi in Northern Algeria]. Réseau Erosion- Bulletin. No. 20 p. 478-484.

WischmeIER H., JOHNSON B., CROSS V. 1971. A soil erodibility nomograph for farm land and construction sites. Journal of Soil and Water Conservation. Vol. 265 p. 189-192.

WischmeIER H., SMith D. 1978. Predicting rainfall erosion losses. A guide to conservation planning. USDA Handbook. No. 537 pp. 59 . 


\section{Mohamed ZOBIRI, Mohamed MAZOUR, Boutkhil MORSLI}

Erozja wodna na stokach marglowych i jej zapobieganie poprzez ochronę systemów wodnych i glebowych w zlewni rzeki Isser w Tlemcen, Algieria

\section{STRESZCZENIE}

Erozja wodna jest głównym problemem na stokach skał marglowych. Tam właśnie procesy erozyjne nasilają się i stwarzają poważne problemy, a wiedza na temat erozyjności i możliwych rozwiązań w odniesieniu do erozji gleb jest nadal niewystarczająca. Celem tej pracy była próba określenia podatności gleb na podłożu marglowym na erozję i ocena skuteczności działań przeciwerozyjnych stosowanych w takim środowisku. Obiektem badań była zlewnia Isser w Algierii, gdzie zastosowano kilka technik przeciwerozyjnych. Analiza instalacji przeciwerozyjnych wykazała, że większość z nich wykonano zgodnie z normami i działały one poprawnie. Ich efektywność była różna. Najbardziej odpowiednie i skuteczne okazały się stopnie ziemne. Efektywność ziemnych struktur ocenia się na podstawie stabilności, trwałości, kosztów, spłaszczania fali powodziowej i długiego przetrzymywania wody i osadów, co miało pozytywny wpływ na ograniczenie erozji i zamulanie zbiornika. Konstrukcje gabionowe odznaczały się stabilnością i dobrym posadowieniem, ale były bardzo wrażliwe i ulegały uszkodzeniom, co ograniczało ich skuteczność w przeciwdziałaniu erozji. Najmniej pożądane były konstrukcje kamienne, często nieodpowiednie i mało wydajne na takich terenach. Czysto mechaniczne lub biologiczne podejście do problemu jest niewystarczające, dopiero powiązanie mechanicznych rozwiązań z elementami biologicznymi może przynieść pożądany skutek.

Słowa kluczowe: efektywność ochrony wody i gleby, erozja, margiel, zamulanie, zlewnia rzeki Isser 